\title{
Demographic Change and Transition in Southeast Asia: Implications for Higher Education
}

\author{
Muftahu Jibirin Salihu \\ National Higher Education Research Institute, Universiti Sains Malaysia, Malaysia
}

Received July 13, 2019; Revised January 3, 2020; Accepted January 15, 2020

Copyright $\subseteq 2020$ by authors, all rights reserved. Authors agree that this article remains permanently open access under the terms of the Creative Commons Attribution License 4.0 International License

\begin{abstract}
Demographic change and transition are proven to have significant implications for access to education as well as its demand and supply, particularly in developing countries. Consequently, this paper focuses on assessing the effects of the rapid growth of the youth population in Southeast Asia with specific attention to higher education enrolment. In conducting the study, secondary data related to the impact of demographic changes in higher education in the region were used through the review of the existing literature. As such, content analysis was employed to analyze and represent the data collected. Findings revealed that the growth of youth population can lead to increased demands in higher education enrolment and learning. It was also discovered that the expansion of higher education in Southeast Asia led to the enhancements of their higher education system that contributed to attracting more international students, thereby contributing to youth population growth. Homogeneously, the findings of the study also suggested the need for readiness from higher education institutions to cater for the increasing demands in higher education in developing countries due to continuous changes in demographic factors such as population growth. Equally, the paper proposed that the policymakers consider a transformation through modernisation of higher education act focusing on training more educators in relation to skill and entrepreneurship roles as well as making education more accessible and flexible to students.
\end{abstract}

Keywords Demography, Change, Southeast Asia, Higher Education, Population Growth

\section{Introduction}

Demographic changes demonstrating continuous increase in population are becoming apparent in developing countries worldwide. Thus, this demographic phenomenon presents significant implications for various aspects, particularly in the field of education. According to the International Institute for Educational Planning (IIEPUNESCO) (2019), demographic change can have significant impacts on education service demands and provision in various ways that can either be considered as opportunities or risks. This suggests that demographic transition can have significant implications for the demand and supply of higher education, particularly in developing countries.

Southeast Asia is a region with the majority of nations having developing economies. The countries that make up Southeast Asia are Brunei, Cambodia, Timor-Leste, Indonesia, Laos, Malaysia, Myanmar, The Philippines, Singapore, Thailand, and Vietnam (Center for Southeast Asian Studies, 2019). Recent trends suggest that this region is experiencing rapid changes in terms of demography due to several factors such as moving towards liberalization and diversification, among others (Ratanawijitrasin, 2015). According to the same author, the changes in trends and demography coupled with the influence of domestic and global forces contribute to the significant transformation of the higher education sector in the region. As such, countries in the Southeast Asian region are currently experiencing new challenges such as increased competition, demands for talent human resources, and demand and supply issues in the higher education sectors (Chapman, 2009; Ra, Chin, \& Liu, 2015).

This paper focuses on assessing the effects of the rapid growth of the youth population in Southeast Asia on higher education enrolment. There are some countries in Southeast Asia such as Malaysia that increased the number of their degree awarding institutions with about 500 higher education institutions (HEIs) in 2007 in order to cater to the growing rate of the youth population (Arokiasamy et al., 2009). In line with this, it is important to consider how these countries with increased HEIs cater to the possibility of increased supply with less demand in the future should stabilization of demographic transition occur. 


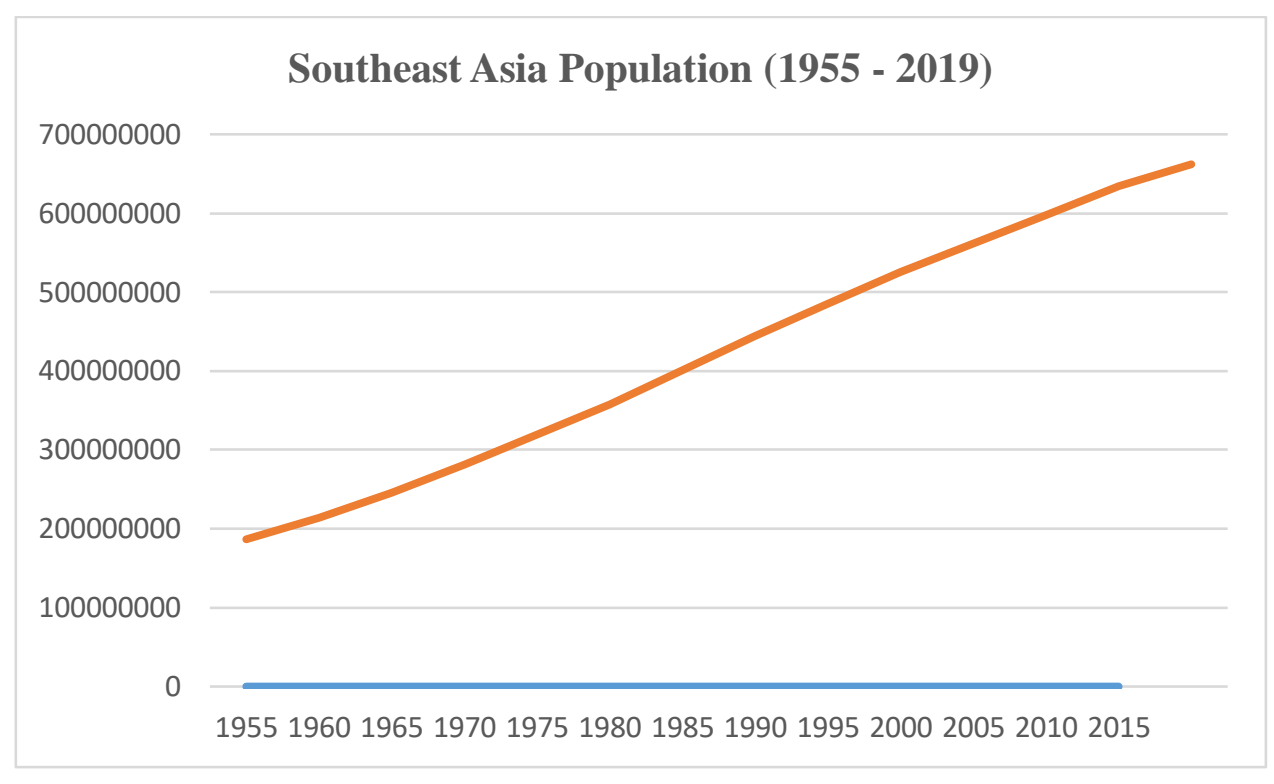

Figure 1. Population of Southeast Asia from 1950-2015 (Worldometers, 2019)

Figure 1 shows the population of Southeast Asia from 1950 to 2015. As seen in the chart, the population trend in the region has continuously been rising every year from 164,524,620 in 1950 to 662,375,294 in 2015 based on the United Nations estimates (Worldometers, 2019). As highlighted in the same report, Southeast Asia's population is about 8.59\% of the total world population. It is also forecasted that the population will continue to increase in the next decade. According to World Atlas (2019), the top three most populated countries in Southeast Asia are Indonesia, the Philippines, and Vietnam (see Table 1).

Table 1. Population Growth Trends in Southeast Asia from 2015-2019 (Worldometers, 2019)

\begin{tabular}{|c|c|c|c|c|c|c|c|c|c|c|c|}
\hline Year & Population & $\begin{array}{c}\text { Yearly \% } \\
\text { Change }\end{array}$ & $\begin{array}{c}\text { Yearly } \\
\text { Change }\end{array}$ & $\begin{array}{c}\text { Migrants } \\
\text { (net) }\end{array}$ & $\begin{array}{c}\text { Median } \\
\text { Age }\end{array}$ & $\begin{array}{c}\text { Fertility } \\
\text { Rate }\end{array}$ & $\begin{array}{l}\text { Density } \\
\left(\mathbf{P} / \mathbf{K m}^{2}\right)\end{array}$ & $\begin{array}{l}\text { Urban } \\
\text { Pop \% } \\
\end{array}$ & $\begin{array}{c}\text { Southeast Asia's Share } \\
\text { of World Pop }\end{array}$ & $\begin{array}{c}\text { World } \\
\text { Population }\end{array}$ & $\begin{array}{l}\text { Southeast Asia's } \\
\text { Rank within Asia }\end{array}$ \\
\hline 2019 & $662,375,294$ & $1.03 \%$ & $6,738,718$ & $-280,218$ & 28.80 & 2.33 & 153 & $329,850,428$ & $8.60 \%$ & $7,714,576,923$ & 3 \\
\hline 2018 & $655,636,576$ & $1.06 \%$ & $6,856,536$ & $-280,218$ & 28.80 & 2.33 & 151 & $322,842,932$ & $8.60 \%$ & $7,632,819,325$ & 3 \\
\hline 2017 & $648,780,040$ & $1.09 \%$ & $7,004,243$ & $-280,218$ & 28.80 & 2.33 & 149 & $315,797,197$ & $8.60 \%$ & $7,550,262,101$ & 3 \\
\hline 2016 & $641,775,797$ & $1.13 \%$ & $7,165,951$ & $-280,218$ & 28.80 & 2.33 & 148 & $308,708,804$ & $8.60 \%$ & $7,466,964,280$ & 3 \\
\hline 2015 & $634,609,846$ & $1.22 \%$ & $7,456,415$ & $-249,600$ & 28.50 & 2.35 & 146 & $301,578,981$ & $9.10 \%$ & $7,383,008,820$ & 3 \\
\hline
\end{tabular}




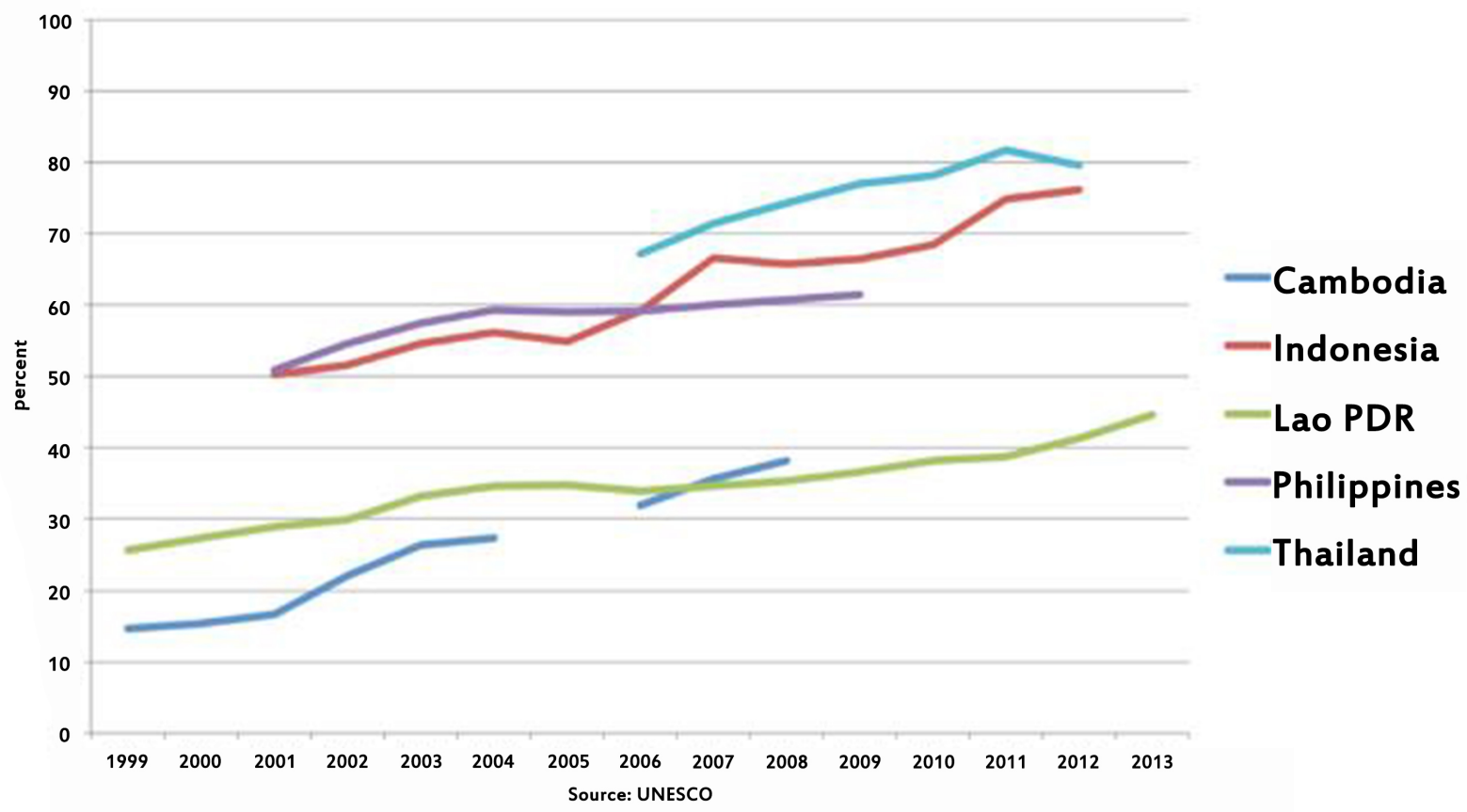

Figure 2. Secondary school enrolment rates in Southeast Asia from 1999-2013 (Juenemann, 2015)

As highlighted in both Figures 1 and 2, the population trend in Southeast Asia is increasing yearly. Population has more than doubled since 1950. According to Jones (2013), the demographic history of the Southeast Asian countries in the last couple of centuries has become among the frontier expansion. Statistics (see Figures 3 and 4) also show that the increase in enrolment rates in secondary education and increasing growth rate of enrolment by international students in higher education translate into the increase in the number of students seeking higher education learning (Kuroda et al., 2018; Tremblay, Lalancette, \& Roseveare, 2012). This is consistent with the theory of demographic transition suggesting that changes in birth and death rates are significantly associated with the growth rate of population.

Table 2. Top Countries of Origin of Foreign Students by Regions of the World, Southeast Asia 2011 (ICEF Monitor, 2014)

\begin{tabular}{|c|c|c|}
\hline & $\begin{array}{c}\text { Students Abroad (In } \\
\text { Thousands) }\end{array}$ & $\begin{array}{c}\text { \% in OECD } \\
\text { Countries }\end{array}$ \\
\hline Vietnam & 61 & $82 \%$ \\
\hline Malaysia & 61 & $80 \%$ \\
\hline Indonesia & 43 & $63 \%$ \\
\hline Thailand & 28 & $86 \%$ \\
\hline Singapore & 21 & $94 \%$ \\
\hline
\end{tabular}

\section{Number of Universities and Enrolment}

Continuous population growth in Southeast Asia has certain implications for higher education. For one, the need to increase the number of universities has become the focus of some of the countries in the region in order to cater to the growing demand in higher education. In the 2014 report by the United Nations Educational, Scientific and Cultural Organization (UNESCO) about examining dynamics in association with the growth of graduate education in Asia with particular focus on Southeast Asian middle-income countries, it was found that the number of global higher education enrolment has increased from 32.6 million in 1970 to 182.2 million students in 2011 wherein $46 \%$ is from East and South Asia. Moreover, the Southeast Asian governments have been investing majorly in education in pursuit of achieving developmental parity (Juenemann, 2015). As a result, several countries from the regions of Southeast and East Asia have transitioned from elite systems to massification (UNESCO, 2014). Figure 3 shows the gross enrolment ratios for bachelor's degree programmes by country in Asia.

As illustrated in Figure 3, the gross enrolment in Asia is highlighting an increasing trend in each country. According to UNESCO (2014), the increase in higher education enrolment in Asian countries is fuelled by various factors such as demographic trends, policy decisions, higher participation rates in basic, primary, and secondary education, and widening access to bachelor's degree programmes, among others. Thus, as the number of enrolment grows, the need to expand and increase the number of universities became part of the solutions of each country's decision-makers. 


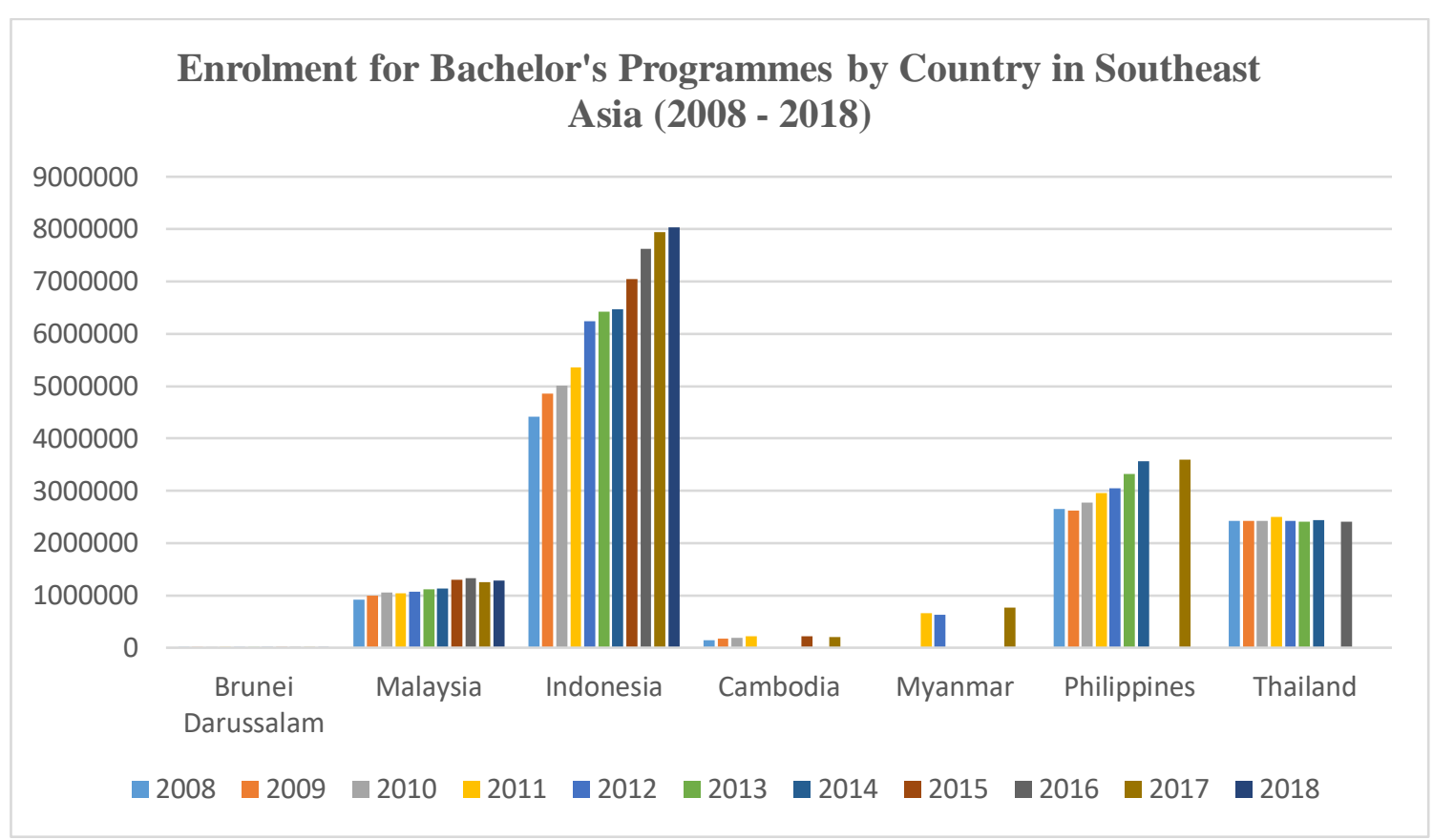

Figure 3. Gross enrolment ratios for bachelor's degree programmes by country from 2008-2018 (UNESCO, 2014)

\begin{tabular}{|c|c|c|c|c|}
\hline \multirow[t]{2}{*}{ Countries } & \multicolumn{2}{|c|}{$\begin{array}{l}\text { Number of public higher } \\
\text { education institutions }\end{array}$} & \multicolumn{2}{|c|}{$\begin{array}{l}\text { Number of private higher } \\
\text { education institutions }\end{array}$} \\
\hline & 2010-12 & 2015-17 & 2010-12 & 2015-17 \\
\hline Brunei $^{25}$ & 4 & 6 & - & 6 \\
\hline Cambodia & 38 & 54 & 46 & 72 \\
\hline Indonesia & 83 & 81 & 2,818 & 2,431 \\
\hline Lao PDR ${ }^{26}$ & 22 & 85 & 31 & 83 \\
\hline Malaysia & 20 & 20 & 500 & 599 \\
\hline Myanmar & $171^{27}$ & 169 & - & $35^{28}$ \\
\hline The Philippines ${ }^{29}$ & 220 & 231 & 1,636 & 1,712 \\
\hline Singapore & 5 & 9 & 47 & 30 \\
\hline Thailand & 98 & 66 & 73 & 455 \\
\hline Vietnam & 187 & 64 & 29 & 305 \\
\hline
\end{tabular}

Figure 4. Number of public and private higher education institutions in Southeast Asian countries from 2010-2017 (Atherton et al., 2018)

Several governments across the Asian region have encouraged the expansion of private higher education in order to shift students away from the heavily subsidized public sector (UNESCO, 2014). As such, the expansion of private higher education has become a focus since a number of countries already have private higher education sectors in operation. Discovery (2018) noted that Southeast Asia has already achieved a $99 \%$ literacy rate wherein the youth aged between 15 and 24 were reported to be $91 \%$ literate on average. Besides, some countries in Southeast Asia such as the Philippines and Indonesia already have a strong tradition of private higher education wherein the majority of students are enrolled in and attending private institutions (Altbach, 2015).

Figure 4 displays the number of public and private HEIs in Southeast Asian countries from 2010 to 2017. From the figure, Indonesia has the highest number of public and private HEIs, followed by the Philippines and then Malaysia. This suggests that Indonesia, the Philippines, and Malaysia are among the top countries that invest in expanding their HEIs in response to meeting growing demands. It is also highlighted in Figure 4 that there are some Southeast Asian countries that have a decrease in HEIs, particularly in public HEIs. Accordingly, there are a number of reasons that can contribute to the decrease in HEIs such as lack of or inadequate funding from the 
government for maintaining public HEIs and increase in public expenditure allocated to higher education, among others (UNESCO, 2014).

\section{International Students}

Another factor that contributes to the increase in enrolment in higher education in Southeast Asia is the increase in the enrolment rates of international students. As defined by UNESCO (2014, p. 33), 'International (or mobile) students are defined as students who have crossed a national border and moved to another country with the objective of studying'. The main reason why international students are attracted to enrol in higher education in Southeast Asia is because of the enhancements in higher education systems in the region. In addition, governments and educational policies in the majority of the Southeast Asian countries support equal access to higher education, thereby influencing the growth of international students in the region (Atherton et al., 2018). Thus, decreasing trends of outbound mobility (shown in Figure 5) and increasing trends of inbound mobility among Southeast Asian students indicate the increasing influence of local and/or regional educational capacity of Southeast Asian countries (Yahaya, 2018). The majority of international students are enrolling in undergraduate and doctoral programmes.

\section{Southeast Asian Outbound Students by Destination in 2012}

(Total $=224,483$ )

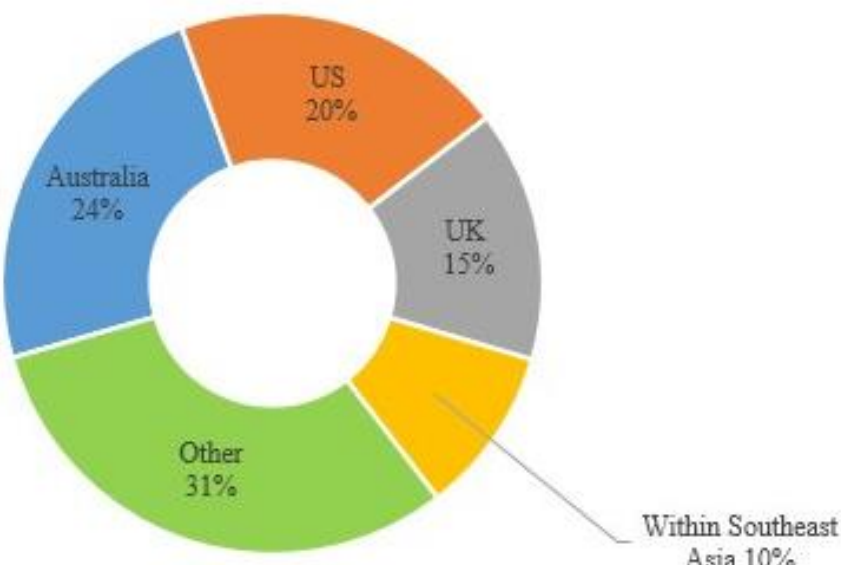

Figure 5. Southeast Asian outbound students by destination in 2012 (Yahaya, 2018) 


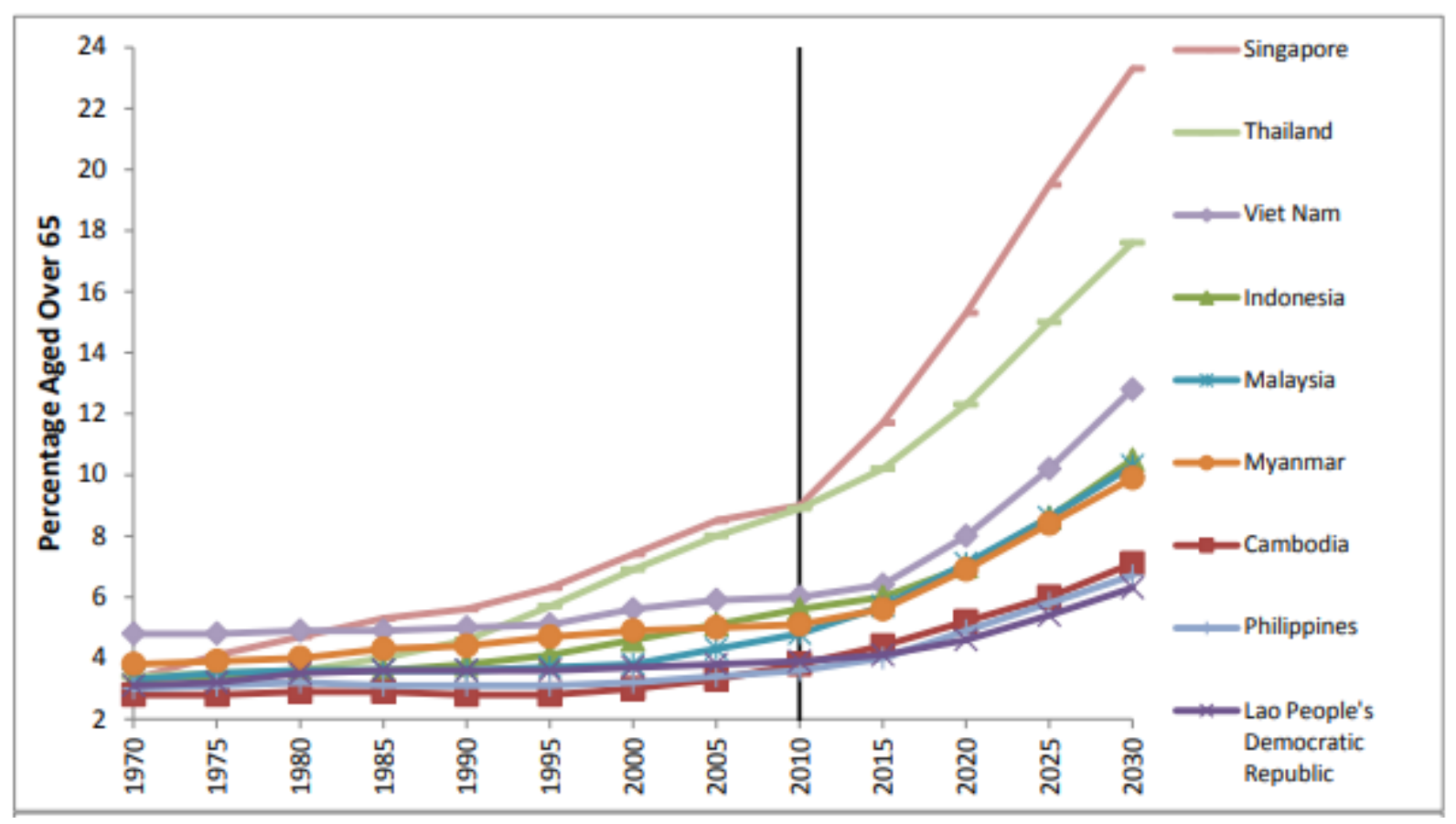

Figure 6. Percentage of population aged over 65 from 1970-2030 (Jones, 2013)

\section{Expansion of Higher Education in Southeast Asia}

The expansion of higher education in Southeast Asia led to the enhancements of their higher education systems that contributed to attracting more international students. Interestingly, the Southeast Asian region is among those that witnessed rapid demographic changes in the world, but it needs to be noted that there is considerable diversity in the demographic profiles (Park et al., 2012). For example, the majority of the low and middle-income countries in the region have a youthful age structure such as in the Philippines, whereas some high-income countries such as Singapore and Malaysia have aging age structure (shown in Figure 6) (Altner, 2019; Jones, 2013; Park et al., 2012).

The rise of population and the increase in the number of international (mobile) students led to the need for the expansion of higher education in the Southeast Asian region in order to increase capacity to offer graduate programmes and to promote diversification and inclusion as part of the enhancements of their higher education systems (UNESCO, 2014). It was further highlighted by Ratanawijitrasin (2015) that there are four major trends that characterized the changes and expansion of the higher education landscape in Southeast Asia, namely Massification, Diversification, Marketization, and Internationalization. In the following section, the expansion of higher education in selected countries in Southeast Asia is described.

\section{Malaysia}

Since 2000, the Malaysian higher education system has grown and expanded rapidly leading to the rapid increase in enrolment, particularly at the graduate level (Chapman \& Chien, 2015). Accordingly, the number of students enrolled in the graduate level has increased from about 21,000 in 2000 to approximately 85,200 in 2010 (UNESCO, 2014). This has become the inspiration for the Malaysian government to expand its higher education with the goal of accelerating the production of doctorates ( $\mathrm{PhD}$ holders) in the country (Clark, 2014). Therefore, as part of its higher education expansion strategy, the Malaysian government has focused on its research capability and in assisting in financing graduate students. In line with this, it is the aim of Malaysia to increase its higher education participation rate from $40 \%$ (current) to $50 \%$ by 2020 (UNESCO, 2014).

The Star Online (2018) news report shared important details from the Ministry of Higher Education's secretarygeneral, Tan Sri Dr. Noorul Ainur Mohd Nur, during the Going Global 2018 Conference concerning the state of the higher education industry in Malaysia. It was found that the region aimed at targeting 200,000 international students by 2020 and 250,000 by 2025. As of 2018, Malaysia has received 170,000 students from 135 countries such as Asia, Europe, the Middle East, and Africa. The Ministry of Education's secretary-general prided that the Malaysian higher education's accessibility has improved from only $14 \%$ in the 1980 s to more than $44 \%$ in 2016 . The $44 \%$ rate of Malaysia was considered higher than most of the ASEAN (The Association of Southeast Asian Nations) 
countries in terms of gross enrolment ratio and even in the world average of $37 \%$.

The growth and landscape of the Malaysian HEIs has also been influenced by different incidents in the region, which also pose certain implications. For one, Sani and Mustafa (2019) noted that the general election in 2018 led to the merging of the Ministry of Education through the leadership of Education Minister, Dr. Maszlee Malik. The merger served as the platform for planning, implementation, and management strategies, operations of pre-school to higher education, and even lifelong learning. Diversity and education also served as the Malaysian Ministry of Education's mission with the intake of public universities, community colleges, polytechnics, and public skills training institutions in June 2018. The Ministry of Education vowed to create technical and vocational training (TVET) to serve as students' first choice of studies in the next five years.

\section{Thailand}

Similar to Malaysia, the number of enrolment at the graduate level in Thailand has increased from about 193,000 in 2007 to approximately 196,000 in 2012, particularly in the doctorate level (UNESCO, 2014). In response to this, the Thai government has been working with the universities in the country in order to achieve a common belief that the focus must be placed on developing graduate education and enhancing graduate enrolment (Michael, 2018). The Thai government has allocated an additional 5.83 billion Baht in order to support educational reform (Fry \& Bi, 2013). It is the goal of the Thai government to become the education hub of ASEAN. Therefore, part of its expansion strategy is to establish more universities and HEIs.

Knoema (2019) showed that the gross enrolment ratio in tertiary education in Thailand in 2015 was $48.9 \%$, which indicated an increase to an average rate annual rate of $4.84 \%$. In 1996, Thailand's gross enrolment was only $20.7 \%$ and eventually increased to $48.9 \%$ in 2015 . The growth development is represented in Figure 7.

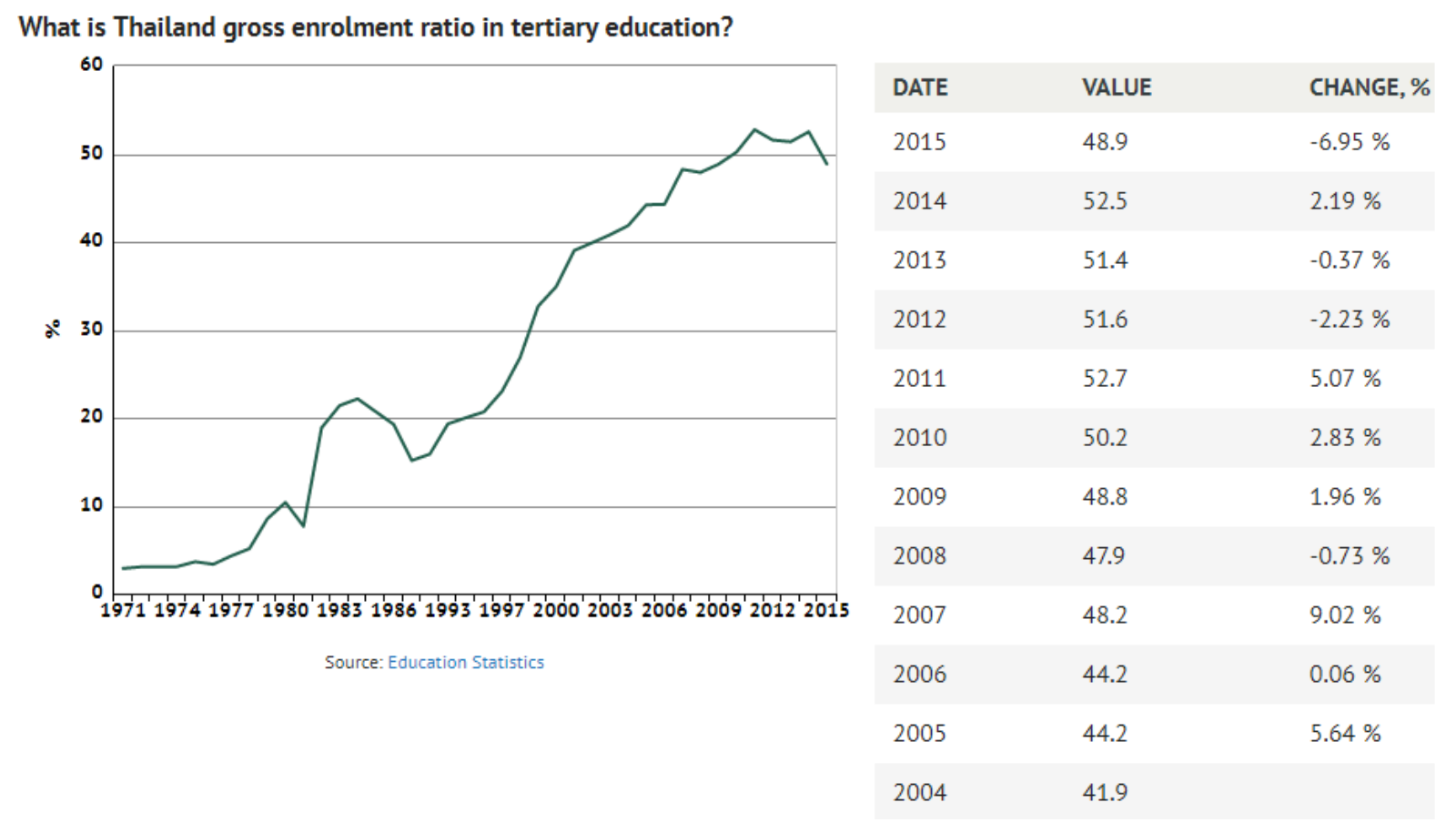

Figure 7. Gross enrolment ratio of Thailand's tertiary education (Knoema, 2019) 


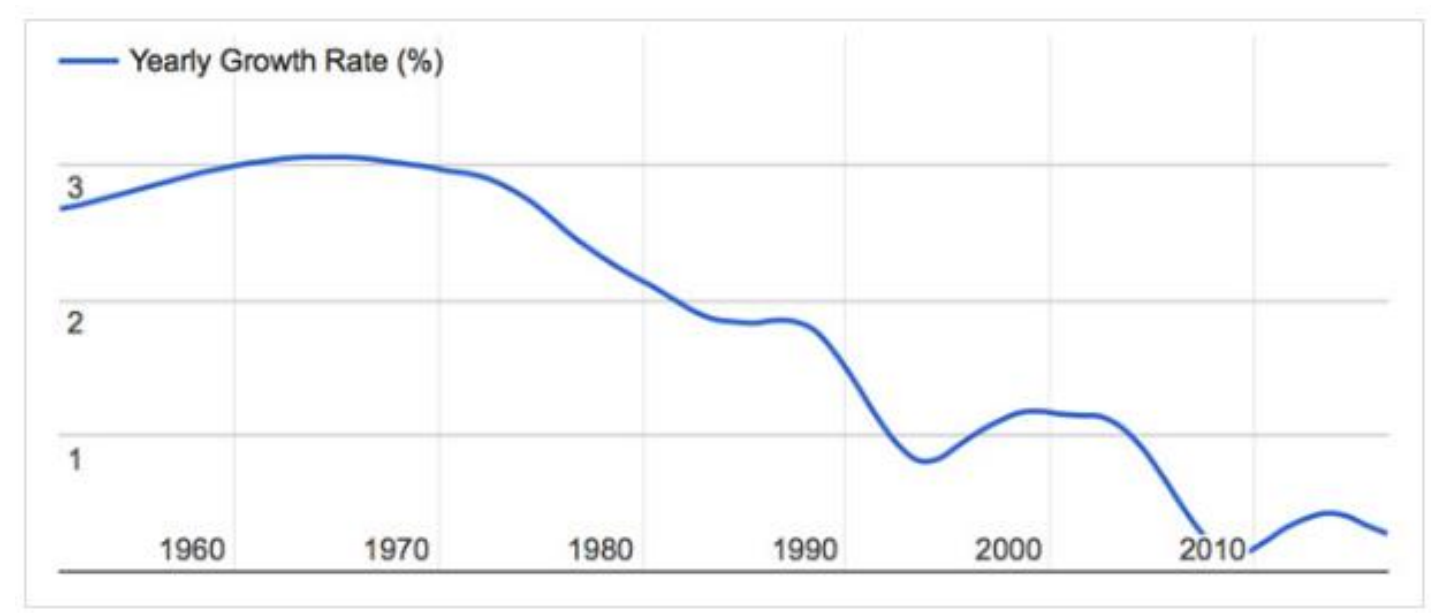

Annual population growth rates for Thailand, 1960-present. Source: United Nations

Figure 8. Annual growth rate in Thailand from 1960-2017 (ICEF Monitor, 2016)

The increase of enrolment in universities served as a reflection of the demographic growth in Thailand. According to ICEF Monitor (2017), Thai higher education expanded rapidly in the 1980s, which seeks to keep pace with the growing demand of the region. In 2017, around 170 colleges and universities were operating in Thailand, including 71 private universities. The expansion of the Thai system in the recent decades aided the establishment of the private institutions and somehow restructured some public universities, in the form of new and independent campuses. With the quick shifting of the demographic balance, the number of students enrolled in Thai universities also increased, but eventually declined, especially in 2010. Based on the report from the ICEF Monitor (2016), Figure 8 shows the country's low birth rate in 2010, which has been potentially due to the earlier national policies that aimed at reducing fertility rates. This led to the decline of population growth rate in Thailand - as in 3\% in the 1960s and 1970s to only .3\% in 2017.

With the decrease of growth rate in Thailand in 2010, there were only under 2.5 million students enrolled in tertiary education. The downward trend continued that only 2.2 million students were enrolled in 2015, which resulted in reduced capacity and cost struggles of institutions. Sadly, the number of prospective students continued to decrease, where only 80,000 Thai students applied to sit at the national university admissions in 2016 compared with 100,000 students in the previous year. At the same time, there were fewer than 110,000 spaces available in Thai's central university admission system (CUAS) in 2017. This was also considered a sharp decline from more than 150,000 seats offered two years ago (ICEF Monitor, 2017).

Thailand's ageing population was also regarded as one of the contributors to the decline in university enrolees. Thailand was also considered unique compared with other Southeast Asian countries, where the increasing working age population was helping the gross domestic product (GDP) growth and productivity. In Thailand, the 'National Economic and Social Development Board projects' or the Thais 21 years old and below would belong to the $20 \%$ population in 2014 - a dramatic decline from around 62\% in the 1980. Again, the core issue pointed to low birth rate (ICEF Monitor, 2016).

\section{Philippines}

Recent demographic trends have contributed to significant challenges for the Philippines in terms of achieving its education-related sustainable goals (SalazarClemena, 2006). In response to this, the Philippine government made an effort to enhance its higher education system as part of its progression and expansion strategy towards achieving the provision of quality education and lifelong learning opportunities for all (Chao, 2018). The higher education in the Philippines consists of both public and private institutions with a total of 176 public HEIs and 1,443 private HEIs (Worldbank.org, n.d.). In 1994, the government established the Commission on Higher Education (CHED) in order to govern the overall aspects of HEIs. In addition, education policy reforms have been enacted in pursuit of systematically redesigning the overall education system in the country (Chao, 2018). For example, the education system has already shifted to the $\mathrm{K}$ to 12 structure and educational reforms have provided free tuition fees for students in undergraduate programmes in public HEIs (Chao, 2018).

The Philippines' current distribution of HEIs according to institutions indicates that the grand total is almost 2,000. As seen in Figure 9, the CHED (2019) showed that there were more private HEIs than state and local colleges and universities. 


\begin{tabular}{lc}
\multicolumn{1}{c}{ Institution Type } & Count \\
\hline State Universities and Colleges (SUCs) & 112 \\
\hline Local Colleges and Universities (LCUs) & 107 \\
Other Government Schools (OGS, CSI, Special HEIs) & 14 \\
Private Higher Education Institution & 1,710 \\
\hline Grand Total & 1,943 \\
\hline - Figures exclude SUCs Satellite, Extension Campus and External Study Center & \\
- Based on the submission of higher education institutions, as compiled by OPRKM-Knowledge Management Division &
\end{tabular}

Figure 9. Higher education institutions in The Philippines from 2016-2017 (CHED, 2019)

Plaza (2018) underscored that the Philippine's National Development Plan highlighted that the number of higher education institutions in the region is 10 times more than its neighbouring countries. However, the country lagged behind in terms of producing researchers, innovators, and solutions providers, which can contribute to economic growth and development. There were only 81 researchers per million population in the Philippines compared with 205 in Indonesia and 115 in Vietnam. Meanwhile, the gross tertiary enrolment rate in the region has grown to 4.1 million in 2016 from only 2.2 million in 1999, which indicated an expansion and increase in the higher education participation. The enrolment rates for college students were also expected to expand, especially after the bold decision of President Rodrigo Duterte to make education free in state colleges and universities in 2017. However, despite the tuition-free announcement, there remains a need for a new generation of researchers and innovators in the region.

\section{Conclusion and Recommendations}

This paper discussed the implications of demographic changes for higher education in Southeast Asia. Accordingly, continuous population growth in Southeast Asia has certain implications for higher education. This paper focuses on assessing the effects of the rapid growth of the youth population in Southeast Asia on higher education enrolment. In order to address the research objectives, the impact of demographic changes in higher education institutions in Thailand, Malaysia, and the Philippines were analyzed. These countries were selected for analysis due to the current trends in demographic changes which is not as apparent compared to other countries in the Southeast Asian region. Whilst it is true that demographic changes are being experienced across the Asian region, Thailand, Malaysia, and the Philippines have the highest number of public and private HEIs with the most implications for HEIs as suggested from the results of this study. Findings revealed that the growth of youth population can lead to increased demands in higher education enrolment and learning. It was also found that the expansion of higher education in Southeast Asia led to the enhancements of their higher education systems that contributed to attracting more international students, thereby contributing to the youth population growth as well preparing youth to access quality education for shaping the future of society (Salihu \& Ramadneh, 2015).

This paper argues that the rapid growth of youth population in Southeast Asia contributes to the increasing trends in university enrolment in the region. This means that population growth affects the university enrolment trends in Southeast Asia. According to Jones (2013), the rapid population growth and demographic changes in Southeast Asia contribute to the expansion of educational opportunities. As suggested by the demographic transition theory, the rates of demographic changes contribute to developmental paths. As highlighted by Zaidi and Morgan (2017), education system is one of the major institutions at play in the context of the demographic transition theory. Therefore, demographic changes such as population growth and age structure can impact university enrolment trends and educational planning.

In line with these findings, policy recommendation for policymakers is proposed towards the transformation of higher education through modernization of higher education act focusing on training more educators in relation to taking on new roles in the nation economy and building as well as making education more accessible and flexible to students. This policy recommendation can contribute to enhancing the quality of educational systems in Southeast Asia that can attract more students to enrol (local and international students) so as to mitigate risks of overflowing supply of HEIs in the region.

Indeed, there are several demographics that are affecting 
the education sector in this region though perhaps not only in Asia or southeast, but also another region such Africa and Nigeria as an example (Salihu, 2019). To address certain challenges, it is essential for the government to be more responsible for developing certain regulations and policies affecting the demographic and education stature of the countries. The government also portrays an essential role in addressing academic issues, especially in the higher education levels. More so, it is important for the government to collaborate well with other sectors in the society, apart from the education sector, so that better policies and regulations on fertility and birth growth rates as well as academic development will be created.

\section{REFERENCES.}

[1] Altbach, P. G. (2015). The Private Sector in Asian Higher Education. Retrieved fromhttp://ejournals.bc.edu/ojs/index .php/ihe/article/viewFile/7009/6226 last accessed 25th December, 2019.

[2] Altner, D. (2019). Demographic Shifts in Asia and Implications for Education Policy and Planning. Retrieved fromhttp://www.iiep.unesco.org/en/ourexpertise/demographic-shifts-asia-and-implicationseducation-policy-and-planning last accessed 25th December, 2019.

[3] Arokiasamy, L., Ismail, M., Ahmad, A. and Othman, J. (2009). Background of Malaysian Private Institutions of Higher Learning and Challenges Faced by Academics. The Journal of International Social Research, 2(8), 60-67

[4] Atherton, G., Azizan, S. N., Shuib, M. and Crosling, G. (2018). The Shape of Global Higher Education: Understanding the ASEAN Region (Volume 3). British Council

[5] Center for Southeast Asian Studies. (2019). Southeast Asian Countries. Retrieved fromhttps://www.niu.edu/cseas/resou rces/countries.shtml

[6] Chao, R. (2018). A Shift Towards Good Quality Higher Education for All. Retrieved fromhttps://www.universityw orldnews.com/post.php?story=20180206100605251 last accessed 25th December, 2019.

[7] Chapman, D. W. (2009). Higher Education Faculty in East Asia. World Bank Group.

[8] Chapman, D. W. and Chien, C. (2015). Dilemmas of Expansion: The Growth of Graduate Education in Malaysia and Thailand. Higher Education Studies, 5(3), 1-10.

[9] Clark, N. (2014). Education in Malaysia. World Education News \& Reviews.

[10] Commission on Higher Education (CHED) (2019). Distribution of Higher Education Institutions by Institution Type: AY 2016-17. Retrieved from<https://ched.gov.ph/di stribution-higher-education-institutions-institution-typeay-2016-17/> last accessed 25th December, 2019.

[11] Discovery. (2018). How Did Southeast Asia Achieve 99\%
Literacy? Retrieved fromhttps://www.discoverydcode.com /dcode/articles/southeast-asia-achieve-literacy/ last accessed 25th December, 2019.

[12] Fry, G. W. and Bi, H. (2013). The evolution of educational reform in Thailand: the Thai educational paradox. Journal of Educational Administration, 51(3), 290-319

[13] Higher Education in Japan. (n.d.). Retrieved from https://www.nier.go.jp/English/educationjapan/pdf/201109 HE.pdf last accessed 25th December, 2019.

[14] ICEF Monitor (12 July 2016). Thai demand for higher education cooling as population ages. Retrieved from $<$ https://monitor.icef.com/2016/07/thai-demand-highereducation-cooling-population-ages/> last accessed 25th December, 2019.

[15] ICEF Monitor (18 October 2017). Thailand's growing supply-demand gap in higher education. Retrieved from $<$ https://monitor.icef.com/2017/10/thailands-growingsupply-demand-gap-higher-education/> last accessed 25th December, 2019.

[16] ICEF Monitor. (2014). Summing Up International Student Mobility in 2014. Retrieved fromhttp://monitor.icef.com/2 014/02/summing-up-international-student-mobility-in2014/

[17] International Institute for Educational Planning (IIEP). (2019). Demographic Shifts in Asia and Implications for Education Policy and Planning. Retrieved from http://www.iiep.unesco.org/en/our-expertise/demographicshifts-asia-and-implications-education-policy-and-planning

[18] Jones, G. W. (2013). The Population of Southeast Asia. Working Paper Series No. 196. Singapore: Asia Research Institute

[19] Juenemann, J. (2015). Report Card on Education in Southeast Asia. Retrieved fromhttp://www.eastbysoutheast .com/report-card-on-education-in-southeast-asia/

[20] Knoema (2019). Thailand - Gross enrolment ratio in tertiary education. Retrieved from<https://knoema.com/atlas/Thail and/topics/Education/Tertiary-Education/Gross-enrolmentratio-in-tertiary-education>

[21] Kuroda, K., Sugimura, M., Kitamura, Y. and Asada, S. (2018). Internationalization of Higher Education and Student Mobility in Japan and Asia. Background paper prepared for the 2019 Global Education Monitoring ReportMigration, Displacement and Education: Building Bridges, Not Walls. Japan International Cooperation Agency

[22] Lee, E. K. (2012). Higher Education Expansion and Economic Growth in Japan and South Korea. PhD Dissertation. University of Pittsburgh.

[23] Michael, R. (2018). Education in Thailand. World Education News \& Reviews.

[24] Park, D., Lee, S., Mason, A. and Elgar, E. (2012). Aging, Economic Growth, and Old-Age Security in Asia. Asian Development Bank.

[25] Plaza, M.A. (2018). Philippine Education System in 2018 Are We Moving Forward? Retrieved from<https://businessmirror.com.ph/2018/09/02/philippine -education-system-in-2018-are-we-moving-forward/> last accessed 25th December, 2019. 
[26] Ra, S., Chin, B. and Liu, A. (2015). Challenges and Opportunities for Skills Development in Asia - Changing Supply, Demand, and Mismatches. Asian Development Bank

[27] Ratanawijitrasin, S. (2015). The Evolving Landscape of South-East Asian Higher Education and the Challenges of Governance. In: Curaj A., Matei L., Pricopie R., Salmi J., Scott P. (eds) The European Higher Education Area. Cham: Springer

[28] Salazar-Clemena, R. M. (2006). Higher Education Research in the Philippines: Policies, Practices, and Problems. In: Meek V.L., Suwanwela C. (eds) Higher Education, Research, and Knowledge in the Asia Pacific Region. Issues in Higher Education. New York: Palgrave Macmillan.

[29] Salihu, M J (2019), THE DEMOGRAPHY SHIFTS IN WEST AFRICAN COUNTRIES: Implication for Access to Higher Education in Nigeria. A paper presented at the 3rd Asia International Multidisciplinary Conference 2019(AIMC2019). 1-2 May 2019 at N24, Universiti Teknologi Malaysia, Johor Bahru, Malaysia.

[30] Salihu, M. J., \& Ramadneh, N. M. A. (2015). The need for global educators? Their significance in the present time and implication for quality education. Global Journal of Educational Studies, 1(2), 67-76.

[31] Sani, R. \& Mustafa, Z. (2019). What lies ahead in 2019 for higher education? Retrieved from<https://www.nst.com.m y/education/2019/01/446228/what-lies-ahead-2019-highereducation> last accessed 25th December, 2019.

[32] Shetty, A. and Shetty, S. (2014). The Impact of Doctors Per Capita on the Mortality Rate in Asia. Int J Med Pharm Sci, 4(9), 10-15.

[33] Star Online (6 May 2018). Redesigning Malaysia's higher education system. Retrieved from <https://www.thestar.co m.my/news/education/2018/05/06/redesigning-malaysiashigher-education-system/>

[34] Statista. (2019). Total fertility rates in Southeast Asian countries in 2018 (in average number of live births per woman). Retrieved fromhttps://www.statista.com/statistics /615676/total-fertility-rates-in-southeast-asia-2016-bycountry/

[35] Tremblay, K., Lalancette, D. and Roseveare, D. (2012). Assessment of Higher Education Learning Outcomes. OECD

[36] United Nations Educational, Scientific and Cultural Organization (UNESCO). (2014). Higher Education in Asia: Expanding Out, Expanding Up - The Rise of Graduate Education and University Research. UNESCO

[37] World Atlas. (2019). Southeast Asian Nations: Sizes, Capitals, And Populations. Retrieved fromhttps://www.wo rldatlas.com/articles/the-southeast-asian-nations-sizepopulation-and-capitals.html

[38] Worldbank.org. (n.d.). The Philippines - Country Summary of Higher Education. Retrievedfromhttp://siteresources.wo rldbank.org/EDUCATION/Resources/278200-

$1121703274255 / 1439264-$

1193249163062/Philippines_CountrySummary.pdf last accessed 25th December, 2019.
[39] Worldometers. (2019). South-Eastern Asia Population. Retrieved fromhttps://www.worldometers.info/worldpopulation/south-eastern-asia-population/ last accessed 25th December, 2019.

[40] Yahaya, N. (2018). Recent Development of International Higher Education in Malaysia. Retrieved fromhttps://www.apaie2018.org/sites/default/files/Speaker $\%$ 20Slides/Recent\%20Development\%20of\%20Internation al\%20Higher\%20Education\%20in\%20Malaysia.pdf last accessed 25th December, 2019.

[41] Zaidi, B. and Morgan, S. P. (2017). The Second Demographic Transition Theory: A Review and Appraisal. Annual Review of Sociology, 43, 473-492 